\title{
Editorial: Circular economy in the built environment
}

\author{
Jacqui Glass \\ Professor of Architecture and Sustainable Construction, Loughborough \\ University, Loughborough, UK \\ David Greenfield \\ Managing Director, SOENECS Ltd, Chair, Institution of Civil Engineers \\ Resources Panel
}

Phil Longhurst

Professor of Environment and Energy Technology, Cranfield University, Cranfield, UK
The built environment is the sector with the largest volume of material flow in the global economy. Initiatives to dematerialise the economy have persisted for many decades. However, achieving step-change reductions in a sector of this scale is a complex challenge that proves difficult to measure, despite city development proving to be effective in raising living standards (Bringezu, 2015). Analysis from the United Nations predicts that more than $66 \%$ of the world's population will be living in urban areas by 2050 , compared with $54 \%$ currently. Matched with an estimated growth of a further 2.5 billion people, the built environment will continue to demand mass volumes of resources (UN, 2014). Evidence-based approaches that deliver real reductions in long-term environmental impact are vital, and this needs to be achieved in cases even where material requirements remain high. Development in this dominant sector demands large-scale technically, socially and financially viable innovations.

It is argued that the concept of the circular economy has the potential for profound change in civil engineering and infrastructure development projects in particular. Central to this principle is maintaining the maximum resource value of materials while preventing losses from the system, so maintaining products and material that are in use is clearly critical. The achievement of this product and process redesign, as well as new business models, will be a key innovation.

This themed issue of Waste and Resource Management (WARM) focuses on examples of new thinking, new evidence and new models that can help the civil engineering, infrastructure and built environment sector to reflect on, engage and embed circular economy principles within its practices.

The papers within this themed issue cover five key aspects that build upon the first WARM circular economy-themed issue, which was published in 2015

- large-scale material reuse within a coastal project

- an investigation into the take up of circular economy principles in construction the concept of material passports to track resource use within the economy

- cost implications for building certified by the Green Building Index, and

- analysis of the structure and values of the European Commission's Circular Economy Package.

The papers in this themed issue build upon the foundations laid out by Julie Hill in the aforementioned issue of WARM; which suggested that the built environment sector focuses on 'managing wastes, rather than preserving resources and value through waste prevention, and moving towards a richer understanding of resource stocks, flows and efficiencies' (Hill, 2015).

Many readers of this journal will be involved with projects in which a change to design, operation or business models could be realised, perhaps to retain the value of materials. While this may not be required by clients per se, solutions that adopt cross-sector collaboration may well be seen as highly desirable. Here, each paper provides evidence of the application of the circular economy concept within the built environment context-and so provides readers with an opportunity to design, inform, assess and guide the process of maximising resource value, while minimising ecological impact. There is much work to be done to achieve general acceptance and understanding of the circular economy concept in a sector that is characterised by unique projects delivered by temporary multi-party organisations, but the evidence provided in this themed issue offer significant food for thought and a catalyst for action and further study.

The first paper (Cross, 2017) explains the outcome of a process of partnering during the Crossrail project to create Europe's largest wetland nature reserve. The scale of material movements involved are substantial, yet pragmatic advice around the formation of a technical panel and effective collaboration over a 17-year period, are applicable to large and small projects alike. The author reassures that project scale should not be a deterrent to innovation, but warns that the Waste 
Framework Directive (European Union Directive 2008/98/EC (EC, 2008)) could be a limiting factor to future project success.

The second paper (Adams et al., 2017) examines the extent to which the concept of circular economy thinking in construction is established. The survey and workshop deliver an important early dataset, which highlights the high level of industry awareness of circular economy concepts, but the authors recognise a need for improved economic arguments, metrics, tools and guidance for designers and subcontractors to implement these principles in practice. The authors leave us contemplating what constitute a 'clear business case for circular economy'-a good trajectory for future WARM papers, perhaps?

The third paper (Luscuere, 2017) examines how Material Passports may have a place in the marketplace in securing value for material use. The author offers some important new perspectives on circular economy, and we would expect to see future outputs from the buildings as material banks project, offering valuable insights that take our understanding of material tracking information well beyond life cycle analysis and environment product declarations.

Cost implications are central to all initiatives and the fourth paper (Chong et al., 2017) reviews the implementation of the Green Building Index rating tool in Malaysia from 2009 as a metric for green building guides. The research identifies the initial cost to achieve certified status and thus the cost premium for green building projects, with implications for developers and policy makers. The paper attends to a wellrehearsed debate about the true cost premium for green buildings, and it would be helpful if future research could articulate the cost increase necessary to deliver a building that embedded circular economy principles. Indeed, such a study might start to provide an answer to Adams and her colleague's call for a clear business case.

Finally, at a time when membership and the influence of the European Commission is never far from the press, the fifth paper from Walter Stahel (2017) presents an analysis and helpful interpretation of the Circular Economy Package (EC CE Package) (CEP, 2017) proposed by the Commission in December 2015. The approach developed from a track-record of environmental protection and waste management, focuses on the continuous flow of material processes. Natural capital, including water and the bioeconomy, as well as manufactured capital, are included. The process adopts a "value-preserving stock management' approach, and examines this in achieving the objective to maintain the value of the products, materials and resources for as long as possible, while minimising the generation of waste. Interestingly, Stahel also alludes to the notion of 'junction issues' - this crystallises the sharp edge of the circular economy debate in the built environment sector and again, offers a useful departure point for subsequent studies.

As the UK, Europe and the world experience political restructuring that is difficult to predict; what remains certain is our dependency on materials in the built environment, and thus the value that circular economy concepts may offer in securing effective use of resources in the future. We hope this themed issue provides readers with a valuable cross-section of current thought on the circular economy.

\section{REFERENCES}

Adams KT, Osmani M, Thorpe T and Thornback J (2017) Circular economy in construction: current awareness, challenges and enablers.. Institution of Civil Engineers - Waste and Resource Management 170(1): 15-24, http//dx.doi.org/10.1680/ jwarm.16.00011.

Bringezu S (2015) Possible target corridor for sustainable use of global material resources. Resources 4: 25-54, http://dx.doi.org/ 10.3390/resources4010025.

CEP (Circular Economy Package) (2017) http://www.europarl.europa eu/EPRS/EPRS-Briefing-573936-Circular-economy-packageFINAL.pdf (accessed 30/03/2017).

Chong H-Y, Tam VWY, Lai WC, Sutrisna M, Wang X and Illankoon IMCS (2017) Cost implications for certified Green Building Index buildings. Institution of Civil Engineers-Waste and Resource Management 170(1): 29-40, http//dx.doi.org/10.1680/ jwarm.16.00019.

Cross M (2017) Wallasea Island Wild Coast Project, UK: circular economy in the built environment. Institution of Civil Engineers - Waste and Resource Management 170(1): 3-14, http//dx.doi.org/10.1680/jwarm.16.00006.

EC (European Community) (2008) The Waste Framework Directive. Directive 2008/98/EC of the European Parliament and of the Council on waste. Off. J. Eur. Commun. L312/3, Art 14.

Hill J (2015) The circular economy: from waste to resource stewardship, part I. Proceedings of the Institution of Civil Engineers - Waste and Resource Management 168(1): 3-13, http://dx.doi.org/ 10.1680/warm.14.00003.

Luscuere LM (2017) Materials Passports: Optimising value recovery from materials. Institution of Civil Engineers - Waste and Resource Management 170(1): 25-28, http//dx.doi.org/ 10.1680/jwarm.16.00016.

Stahel WR (2017) Analysis of the structure and values of the European Commission's Circular Economy Package. Institution of Civil Engineers - Waste and Resource Management 170(1): 41-44, http//dx.doi.org/10.1680/jwarm.17.00009.

UN (United Nations) (2014) World's population increasingly urban with more than half living in urban areas, United Nations, see http://www.un.org/en/development/desa/news/population/worldurbanization-prospects-2014.html (accessed 11/04/2017). 